(C) 2016

\title{
Protection of winter wheat against illnesses and pests at different fertilizer systems
}

\author{
T. Vinnichuk, \\ Candidate of Biological Sciences \\ L. Parminska, \\ N. Gavryliuk
}

National Scientific Center "Institute of Agriculture of NAAS"

The purpose. To study fytosanitory state of sowings of winter wheat at different systems of fertilizing with the purpose of optimization of system of its protection against illnesses and pests. Methods. Field, laboratory, analysis of variance. Results. Results of long-term researches in fytosanitory state of sowings of winter wheat are presented at different systems of fertilizing, and the expediency of chemical crop protection during vegetation is justified. Conclusions. It is fixed that application of collateral products of the pease, the moderate doses of artificial fertilizers, in particular nitrogenous in dose of 60-120 $\mathrm{kg} / \mathrm{hectare}$ at ratio of nitrogen and potassium 1,3:1 in techniques of growing of winter wheat ensures congenial fytosanitory state of sowings and restricts application of fungicides and disinsectants during vegetation of crop. Use of large doses of artificial fertilizers (N300P150K150; N120, N240P80K100 and N180P135K135) promotes increase of numerosity of pathogenic fungi in soil, reinforces strikeness of plants with root rots, floury dew, septoria spot of leaves, invading with sucking pests that causes intense chemical protection of plants.

Key words: winter wheat, phytopathogenic complex, phytophags, pathogenic mycoflora of soil, artificial fertilizers, collateral products of the predecessor, chemical protection.

Comprehensively reasonable use of fertilizers is very important prerequisite for optimizing how technology growing winter wheat in a whole, as its component of integrated plant protection from harmful objects. Fertilizers effect on winter wheat communities and are one of the important factors from which depends the condition of both plants and pests. This effect appears in the microclimate changes in crops, morphological and physiological characteristics of plants, shifting phenological stages of their development, and it is already create conditions for oscillations in a rather wide range of levels of development and reproduction of pests and diseases [1,2].

The use of phosphorus-potassium fertilizers traditionally considered an important measure that improves the phytosanitarycondition ofagrocenoses [3]. It is known that phosphorus-potassium fertilizers promote plant resistance, and excess nitrogen leads to increased reproduction of aphids, mites and other pests and diseases $[4,5,6]$. Of particular importance are potash fertilizers. Increased potassium nutrition of plants provides the formation of their stronger skeletal tissuesandalso cell wall and cuticle that prevents penetration into the cell phytopathogens. Given sufficientpotassiumNutrition in plants activates the biosynthesis of phenolic compoundsthen play an important role in plant immunity $[7,8,9]$.

On the other hand, nitrogen fertilizers, creating excess nitrates in the soil, increase its conductive properties, resulting inphytopathogenicmicromyceta are not only superior but also capable under optimal conditions actively infect susceptible plants. Moreover, according to V.O.Chulkyna and others (2009), with an excess of nitrate bacteria antagonists lose the ability to produce antibiotics and other biologically active substances. Under these conditions, increases the number of pathogenic fungi in the soil and root rot infestation of plants [10].

When developing technologies for growing winter wheat is important to identify this level nutrition of plants, which would help to form a satisfactory phytosanitarycondition of crops and get high grain yield for limited use of pesticides. 
The purpose of research - to study the effect of fertilizersystems on phytosanitary condition of winter wheat crops in order to optimize system to protect it from disease and pests.

Materials and methods off research. The research was conducted in a stationary experiment off section off adaptive intensive technologies cereals and cornNSC "Institute of Agriculture of NAASU" in the field of "Chabany RF" during the 2011-2014 bienniums. The scheme of the experiment included variants with different doses of mineral fertilizers $\left(\mathrm{N}_{60-300} \mathrm{P}_{45-150} \mathrm{~K}_{45-150}\right)$ - var. № 1-7, including the calculated doses to the intended yield of winter wheat-10t / ha (var. 3) and $8 \mathrm{t} /$ ha (var. 4); alternative fertilizer system using only by-products predecessor peas (biological control var. 8); use only mineral fertilizers (var.9); without using of mineral fertilizers and by-products predecessor (var.10 control) (Table 1). Predecessor peas, wheat variety -Benefis Protection system includes seed treatment and application of herbicide.

Accounting for pests and diseases carried by conventional methods phytopathologic and entomological research. Accounting damage of winter wheat by root rots, flaky diseases and head blight was performed by autumn and spring stages of tillering, heading and wax stages for improved VIZR scale. To establish the species composition of insects in crops of winter wheat conducted the survey route, mowing entomological nets, analysis of plants for plant organogenesis stages.

Results. The most common diseases that manifest in all the years of research were powdery mildew (Erysiphegraminis), Septoria leaf (Septoriatritici) and root rot (Cercosporellaherpotrichoides, Ophiobolusgraminis, Fusarium sp., Rhizoctoniacerealis).

The research foundthat a decisive influence on the formation of phytosanitary condition of crops were nitrogen fertilizers, without which it was impossible to obtain high yields of crops of high quality. At the same time, the high doses of nitrogen fertilizers, which positively influenced the growth and development of plants, incrops intensified development of leaf diseases, especially powdery mildew. This explained by changes in the microclimate in a well-developed crops (high humidity, presence of dew), lengthening the duration of the phases of plant development, physiological state of the plants and so on.Especially deteriorated phytosanitary condition of crops by introducing only nitrogen fertilizer or unbalanced of nitrogen and phosphorus-potassium fertilizer.

On average, of 4 years of research, the development of the most common diseases in the experiment - powdery mildew was 3,3-16,5\% and was lowest for using only the by-product predecessor (biological control) $-3.4 \%$ and in the variant without fertilization and by-products predecessor (absolute control) $3.3 \%$ (Table 1).

Table 1. The development of powdery mildew in winter wheat variety of Benefisdepending on the fertilize system, SE HH "Chabany' by-products predecessor -peas, $\%$

\begin{tabular}{|l|l|l|l|l|l|l|}
\hline \multirow{2}{*}{$\begin{array}{l}\text { № } \\
\text { var. }\end{array}$} & \multirow{2}{*}{ Fertilize system } & \multicolumn{4}{l}{ Years of research } \\
\cline { 3 - 6 } & & 2011 & 2012 & 2013 & 2014 & Average \\
\hline & $\mathrm{N}_{60} \mathrm{P}_{45} \mathrm{~K}_{45}$ & 3,0 & 12,0 & 2,5 & 4,0 & 5,4 \\
\hline $1^{*}$ & $\mathrm{~N}_{120} \mathrm{P}_{90} \mathrm{~K}_{90}$ & 5,0 & 15,0 & 4,5 & 3,0 & 6,9 \\
\hline 2 & $\mathrm{~N}_{300} \mathrm{P}_{150} \mathrm{~K}_{150}$ & 5,0 & 35,0 & 7,0 & 15,0 & 15,5 \\
\hline 3 & $\mathrm{~N}_{240} \mathrm{P}_{80} \mathrm{~K}_{100}$ & 4,0 & 32,0 & 4,0 & 15,0 & 13,8 \\
\hline 4 & $\mathrm{~N}_{180} \mathrm{P}_{135} \mathrm{~K}_{135}$ & 4,0 & 37,0 & 5,0 & 20,0 & 16,5 \\
\hline 5 & $\mathrm{~N}_{120} \mathrm{P}_{45} \mathrm{~K}_{60}$ & 3,0 & 27,0 & 5,0 & 15,0 & 12,3 \\
\hline 6 & $\mathrm{~N}_{120}$ & 4,0 & 36,0 & 2,8 & 10,0 & 13,2 \\
\hline 7 & By-products predecessor & 1,0 & 10,0 & 2,0 & 0,5 & 3,4 \\
\hline 8 & $\mathrm{~N}_{120} \mathrm{P}_{90} \mathrm{~K}_{90}$ & 2,0 & 22,0 & 4,3 & 0,5 & 6,7 \\
\hline 9 & Unfertilized & 1,0 & 10,0 & 3,5 & 0,5 & 3,3 \\
\hline 10 & & 0,3 & 6,7 & 1,5 & 3,6 & \\
\hline$L S D_{05}$ & & & & & \\
\hline
\end{tabular}

Note: var.1-8 on the background sideline products predecessor

Development of disease reinforced high doses of fertilizers - $\mathrm{N}_{300} \mathrm{P}_{150} \mathrm{~K}_{150} ; \mathrm{N}_{240} \mathrm{P}_{80} \mathrm{~K}_{100}$ and $\mathrm{N}_{180} \mathrm{P}_{135} \mathrm{~K}_{135}$ to $13,8-16,5 \%$. Below this figure was for making $\mathrm{N}_{60} \mathrm{P}_{45} \mathrm{~K}_{45}-5,4 \%$ and $\mathrm{N}_{120} \mathrm{P}_{90} \mathrm{~K}_{90}-6,7-6,9 \%$. Enhanced the development of the disease by making unbalanced NPK fertilizers. Thus, making only nitrogen 
fertilizer $\left(\mathrm{N}_{120}\right)$ the disease progression was amplified from 6.9 to $13.2 \%$, compared to the variant where made $\mathrm{N}_{120} \mathrm{P}_{90} \mathrm{~K}_{90}$.

Particularly notable was the influence of fertilize system on the development of powdery mildew on weather conditions favorable for disease development. Thus, in 2012 year fertilization doses $\mathrm{N}_{180} \mathrm{P}_{135} \mathrm{~K}_{135}$; $\mathrm{N}_{240} \mathrm{P}_{80} \mathrm{~K}_{100}$ and $\mathrm{N}_{300} \mathrm{P}_{150} \mathrm{~K}_{150}$ strengthened offdisease developmentfrom $10 \%$ in the control to $27-36 \%$; in 2014 - from $0.5 \%$ to $15-20 \%$. Note that for fertilization doses $\mathrm{N}_{60} \mathrm{P}_{45} \mathrm{~K}_{45}$ and $\mathrm{N}_{120} \mathrm{P}_{90} \mathrm{~K}_{90}$ (ratio of $\mathrm{N}: \mathrm{K}=$ 1,33: 1), especially against the background of making by-products predecessor, the development of powdery mildew was low - 2,5-5,0\% (2011, 2013 and 2014years) or moderate $-12-15 \%$ (2012 year). Reducing the share of potash relative to nitrogen by making $\mathrm{N}_{120} \mathrm{P}_{45} \mathrm{~K}_{60}(\mathrm{~N}: \mathrm{K}=2$ : 1$)$ increased the development of powdery mildew, especially in years with favorable for disease development by weather conditions, in 2012year- from $12-15$ to $27 \%$; in 2014 - from 3.4 to $15 \%$. This is consistent with the author [3] that the optimal phytosanitary point of view is the ratio of nitrogen and potassium of 1,7: 1, which allows you to inhibit the development of disease within ETL. The increase in the ratio of nitrogen relative to potassium to 2 and exacerbates the disease.

Thus, the level of infestation of plants with powdery mildew intensified with increasing doses of mineral fertilizers, especially nitrogen, to $180-300 \mathrm{kga} . \mathrm{i} / \mathrm{ha}$ and by increasing the ratio of nitrogen relative to potassium 2 and above $\left(\mathrm{N}_{120} \mathrm{P}_{45} \mathrm{~K}_{60}\right)$. Below development of a plantdisease was for alternative systems of fertilization (making by-product precursor), the not fertilized background and with moderate doses of fertilizers, especially nitrogen -. 60-120 kg. a.i./ ha where the ratio of nitrogen and potassium was 1,33: 1 .

The need for chemical protection of crops from the disease occurred in 2012 and 2014 years in variants where doses of fertilizers were $\mathrm{N}_{180-300} \mathrm{P}_{80-135} \mathrm{~K}_{100-150}$; by increasing the ratio of nitrogen relative to potassium 2 and above $\left(\mathrm{N}_{120} \mathrm{P}_{45} \mathrm{~K}_{60}\right)$; by introducing only nitrogen fertilizer $\left(\mathrm{N}_{120}\right)$. According to the weather conditions of 2011 and 2013 years had mildew underdevelopment made regardless of doses of fertilizers and crops do not require chemical protection.

Grain crops annually was infestation bySeptoria leaf. The development of the disease in the experiment during the study was mild (0,5 8,0\%) in 2014 to strong (27-35\%) in 2013 (Table 2).

Table 2. Development of Septoria leaf on winter wheat varieties depending on fertilize systems SE HH "Chabany" , 2012-2014.

\begin{tabular}{|l|l|l|l|l|l|l|l|l|l|l|l|l|}
\hline \multirow{2}{*}{$\begin{array}{l}\text { No } \\
\text { var. }\end{array}$} & \multicolumn{3}{|l}{ Benefis } & \multicolumn{3}{l}{ Tsarivna } \\
\cline { 2 - 16 }$y$ & 2012 & 2013 & 2014 & Cep. & 2012 & 2013 & 2014 & Cep & 2012 & 2013 & 2014 & Cep. \\
\hline 1 & 12,0 & 18,0 & 1,5 & 10,5 & 15,0 & 18,0 & 1,0 & 8,0 & 10,0 & 20,0 & 0,5 & 10,2 \\
\hline 2 & 13,5 & 20,0 & 5,0 & 12,8 & 15,5 & 24,0 & 1,0 & 13,5 & 10,0 & 30,0 & 1,0 & 13,7 \\
\hline 3 & 15,0 & 30,0 & 10,0 & 18,3 & 22,0 & 30,0 & 4,0 & 18,7 & 12,0 & 35,0 & 3,5 & 16,8 \\
\hline 4 & 15,3 & 25,0 & 6,0 & 15,4 & 20,5 & 27,0 & 4,0 & 17,2 & 10,0 & 33,0 & 5,0 & 16,0 \\
\hline 5 & 15,0 & 28,0 & 6,0 & 16,3 & 19,0 & 25,0 & 2,0 & 15,3 & 10,0 & 34,0 & 3,0 & 15,7 \\
\hline 6 & 11,2 & 25,0 & 7,0 & 14,4 & 21,0 & 20,0 & 1,0 & 14,0 & 13,3 & 29,0 & 2,5 & 14,9 \\
\hline 7 & 10,0 & 23,0 & 5,0 & 12,7 & 20,0 & 25,0 & 1,5 & 15,5 & 12,5 & 27,0 & 1,5 & 13,7 \\
\hline 8 & 8,0 & 15,0 & 2,0 & 8,3 & 15,0 & 20,0 & 0,5 & 11,8 & 5,0 & 20,0 & 0,5 & 8,5 \\
\hline 9 & 13,3 & 16,0 & 1,0 & 10,1 & 20,0 & 20,0 & 0,5 & 13,5 & 15,0 & 25,0 & 2,0 & 14,0 \\
\hline 10 & 7,0 & 15,0 & 0,5 & 7,5 & 15,0 & 6,0 & 0,5 & 7,2 & 5,0 & 10,0 & 0,5 & 5,2 \\
\hline LSD $_{05}$ & 2,4 & 3,8 & 1,7 & & 2,6 & 3,5 & 1,6 & & 2,1 & 4,2 & 1,5 & \\
\hline
\end{tabular}

As a result of three years of research found that in all varieties of winter wheat development Septoria leaf was higher for the introduction of high doses of fertilizers $\mathrm{N}_{300} \mathrm{P}_{150} \mathrm{~K}_{150} ; \mathrm{N}_{240} \mathrm{P}_{80} \mathrm{~K}_{100} ; \mathrm{N}_{180} \mathrm{P}_{135} \mathrm{~K}_{135}$ and by making only the nitrogen fertilizer $\left(\mathrm{N}_{120}\right)$ on the background of making by-products predecessor. In these variants, the development of disease progression exceeded ETLonvarieties ofBenefis and Tsarivna in 2012 and 2013 years, the variety of Slavna in 2013, which required chemical crop protection. The 
smallest development of disease (below ETL) was observed in variants of biological and absolute control, as well as lower doses of fertilizer $-\mathrm{N}_{60} \mathrm{P}_{4} 5 \mathrm{~K}_{45}$ (var.1) and $\mathrm{N}_{120} \mathrm{P}_{90} \mathrm{~K}_{90}$ (var.2). Treatment plant fungicides for these variants was impractical.

The influence of fertilization on winter wheat infestation root rot was establishment. In average years of research the development of disease in the experiment ranged from 7,2to $16.5 \%$, extension - from 29,1 to $51,9 \%$ (Figure 1).

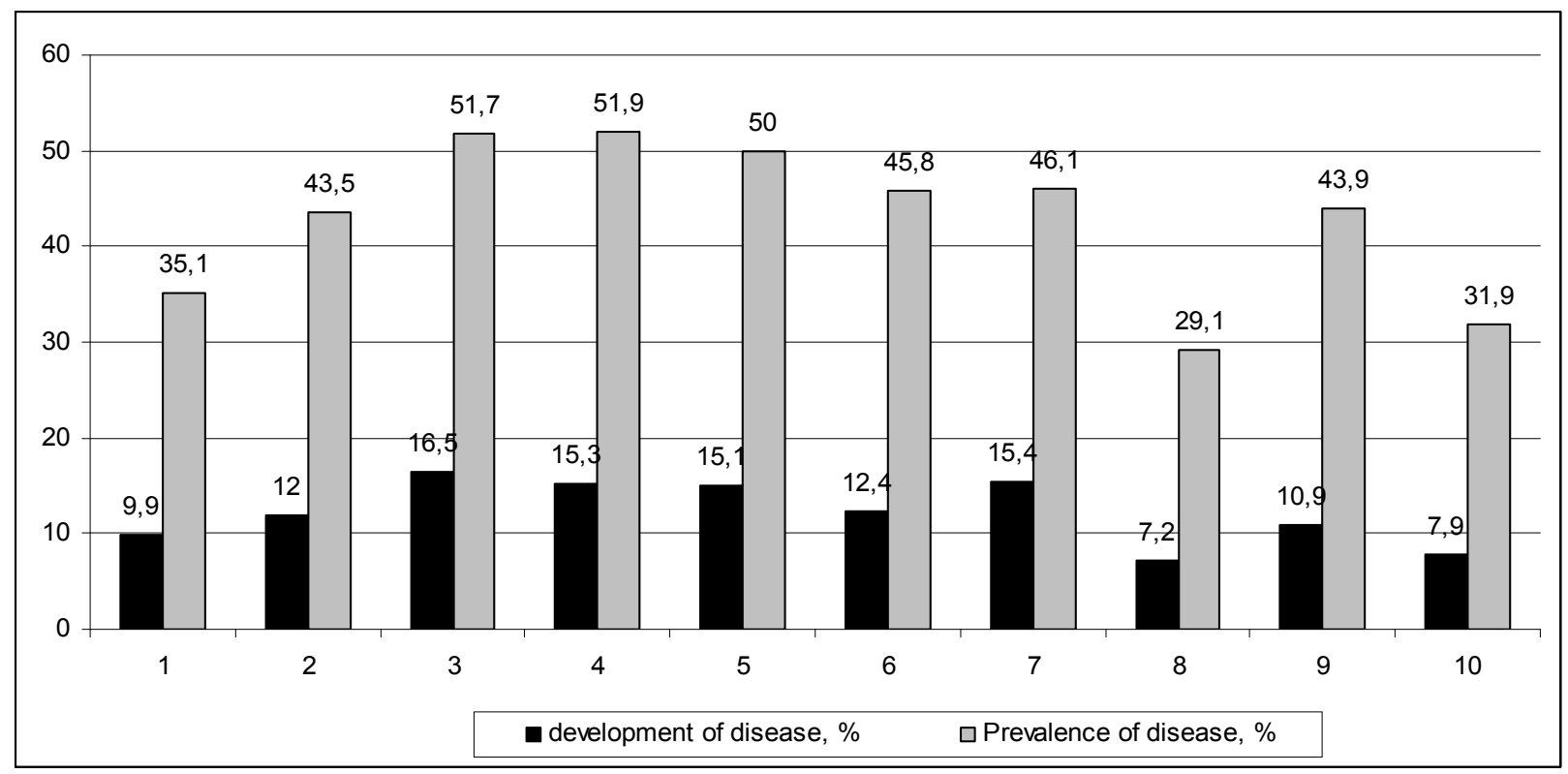

1- $\mathrm{N}_{60} \mathrm{P}_{45} \mathrm{~K}_{45}+\mathrm{By}$-products predecessor; $2-\mathrm{N}_{120} \mathrm{P}_{90} \mathrm{~K}_{90}+$ By-products predecessor; $3-\mathrm{N}_{300} \mathrm{P}_{150} \mathrm{~K}_{150}+\mathrm{By}$ products predecessor; 4- $\mathrm{N}_{240} \mathrm{P}_{80} \mathrm{~K}_{100}+\mathrm{By}$-products predecessor; $5-\mathrm{N}_{180} \mathrm{P}_{135} \mathrm{~K}_{135}+\mathrm{By}$-products predecessor; 6- $\mathrm{N}_{120} \mathrm{P}_{45} \mathrm{~K}_{60}+\mathrm{By}$-products predecessor;7- $\mathrm{N}_{120}$; 8-By-products predecessor.; 9- $\mathrm{N}_{120} \mathrm{P}_{90} \mathrm{~K}_{90}$; 10-Without fertilizer

Fig. 1. Infestationof winter wheat varietiesStolychna root rot depending on fertilizing systems

In 2011 and 2012 years the development of root rots was higher and reached 17,1-18,7\%, extension $58,1-66,0 \%$. Stronger infestation plants for making high doses of fertilizer $-\mathrm{N}_{300} \mathrm{P}_{150} \mathrm{~K}_{150}, \mathrm{~N}_{120}, \mathrm{~N}_{240} \mathrm{P}_{80} \mathrm{~K}_{100}$ and $\mathrm{N}_{180} \mathrm{P}_{135} \mathrm{~K}_{135}$. The lowest infestation root rot was observed in variants absolute $(7.9 \%)$ and biological $(7.2 \%)$ controls and for the at lower doses of fertilizer - $\mathrm{N}_{60} \mathrm{P}_{45} \mathrm{~K}_{45}(9,9 \%)$ and $\mathrm{N}_{120} \mathrm{P}_{90} \mathrm{~K}_{90}(10,9-12,0 \%)$.

Thus, the level of infestation of plant winter wheat powdery mildew, Septoria leaf and root rots intensified with increasing doses of mineral fertilizers, especially nitrogen, to $180-300 \mathrm{~kg}$. a.i. /ha and by increasing the proportion of nitrogen relative to potassium to 2 and above $\left(\mathrm{N}_{120} \mathrm{P}_{45} \mathrm{~K}_{60}\right)$. Below development of disease was for alternative systems of fertilization (plowing by-precursor product), the not fertilizing background and with moderate doses of fertilizers, especially nitrogen - kg.a.i. 60-120 / ha where the ratio of nitrogen and potassium was 1,33: 1 .

We investigated the effect of fertilization on winter wheat population of pests. The entomological complex of winter wheat crops included such pests as cereal aphids, wheat thrips, grain beetlesand cereal fly. It should be not that the number was close to ETL only wheat thrips. The number of other pests was low and considerably under different fertilization systems did not differ. The highest number of pests have cereal thrips- 15,1-33,4 ekz./head.Established that the number of pest was lowest in the absence of fertilizers and by-products predecessor - 14.5 ekz./head and increased by fertilization to 18,1-33,4 ekz./head (Figure 2).Using high doses and unbalanced nitrogen fertilizer resulted an increase in the number of cereal thrips. Thus, in the variant of making only $\mathrm{N}_{120}$ its number was the highest and was $33,4 \mathrm{ekz}$./head. By entering unbalanced high doses of nitrogen fertilizer in relation to phosphorus and potassium the number of pest increased to 27,9 ekz./head $(\mathrm{N}: \mathrm{P}: \mathrm{K}=3: 1: 2,4)$ and to $26,1 \mathrm{ekz} . / \mathrm{head}(\mathrm{N}$ : 
$\mathrm{P}: \mathrm{K}=2,66: 1: 1,3)$. Plowing plant residues predecessor peas in the absence of fertilizer did not significantly affect the number of pests, and their combined use of chemical fertilizers increased the colonization of plants by wheat thripsfrom 15,2 to 18,1-24,8 ekz./head (var. 2, 8 and 9).

Thus, using of high doses or unbalanced fertilizer increases the colonization of winter wheat crop by pests, including wheat thrips, which makes it necessary for them to achieve the level of protection ETL chemical or biological agents.

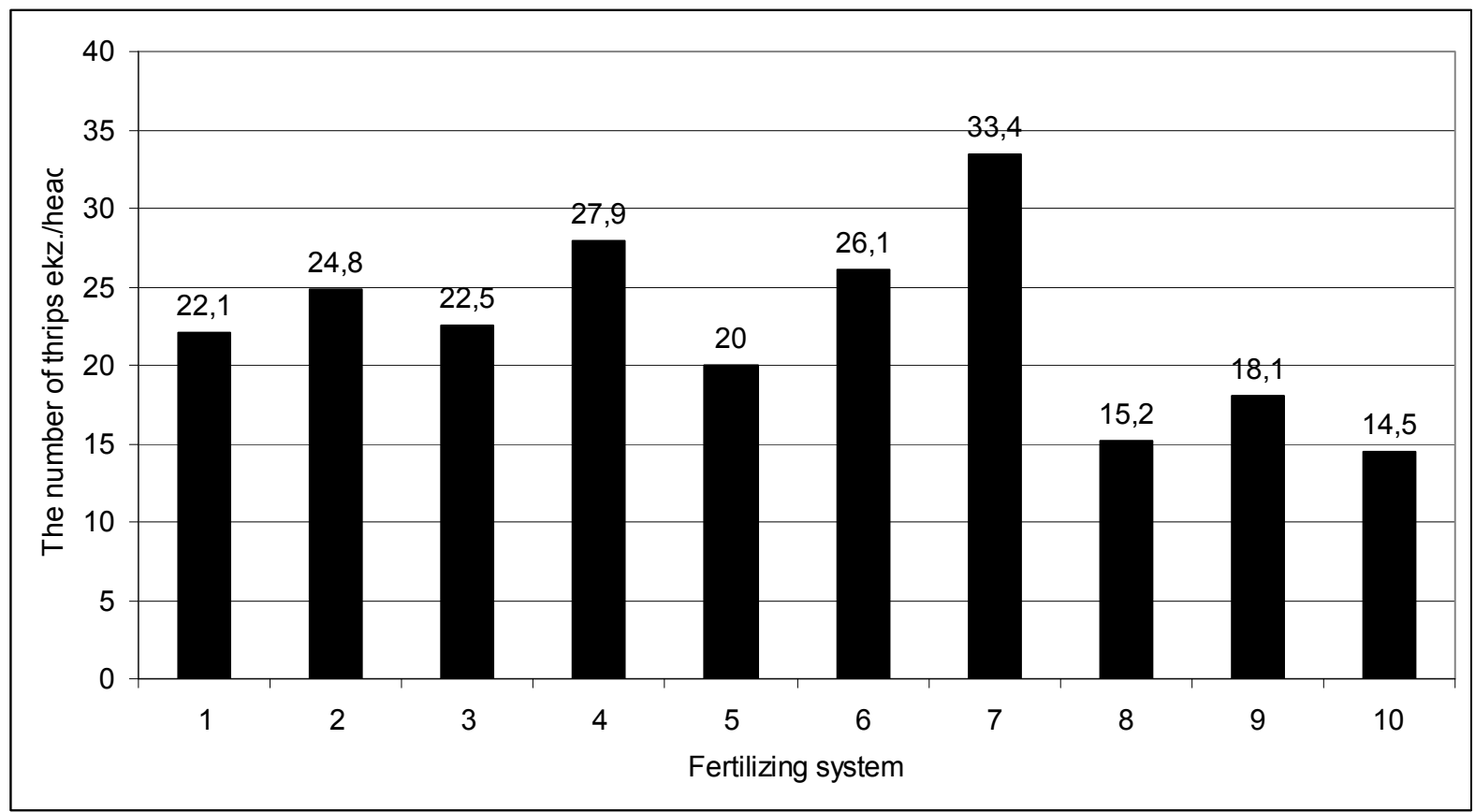

1- $\mathrm{N}_{60} \mathrm{P}_{45} \mathrm{~K}_{45}+$ By-products predecessor.; $2-\mathrm{N}_{120} \mathrm{P}_{90} \mathrm{~K}_{90}+$ By-products predecessor; $3-\mathrm{N}_{300} \mathrm{P}_{150} \mathrm{~K}_{150}+\mathrm{By}-$ products predecessor; 4- $\mathrm{N}_{240} \mathrm{P}_{80} \mathrm{~K}_{100}+\mathrm{By}$-products predecessor; 5- $\mathrm{N}_{180} \mathrm{P}_{135} \mathrm{~K}_{135}+\mathrm{By}$-products predecessor; 6- $\mathrm{N}_{120} \mathrm{P}_{45} \mathrm{~K}_{60}+\mathrm{By}$-products predecessor;7- $\mathrm{N}_{120}$; 8-By-products predecessor.; 9- $\mathrm{N}_{120} \mathrm{P}_{90} \mathrm{~K}_{90}$; 10-Without fertilizer

Fig. 2 Effect of fertilization on winter wheat crops colonization variety Benefisby wheat thrips, ekz./head (SE HH "Chabany' predecessor peas, 2013-2014.)

During the 2004-2009 yearsinvestigated the effects of fertilization of winter wheat on species and quantitative composition pathogenic mikofloryof soil. The scheme of the experiment included variants: a fertilizer doses $\mathrm{N}_{90} \mathrm{P}_{90} \mathrm{~K}_{90} \mathrm{~N}_{135} \mathrm{R}_{135} \mathrm{~K}_{135}$ and against the background of making by-products predecessor peas; of plowing by-product predecessor peas; making only fertilizer doses $\mathrm{N}_{90} \mathrm{P}_{90} \mathrm{~K}_{90}$ and control (without fertilizer and by-products predecessor).

As a result of mycological analysis in experiment determined 34 species of fungi belonging to 12 genera. By pathogenic fungi belonged to 11 species: Alternariaalternata (Fr.) Keissl.; Fusariumculmorum (Sm.) Sacc., Fusariumoxysporum (Schlecht.)Snyd. etHans, FusariummerismoidesCda, FusariumsambucinumFuck. var. minusWr., Fusariumsolani (Mart) Sacc. var. argillaceum, GliocladiumrozeumBainier; Myrotheciumroridum Tode: Fries, Penicilliumviridicatum Westling, Rhizopusstolonifer (Ehrenberg: Fries) Vuill, Aspergillusnigervan Tieghem.

Number of pathogenic fungi in the experiment ranged from 16,6 to 22,0 thousand. / $G$ soil (Figure 3). 


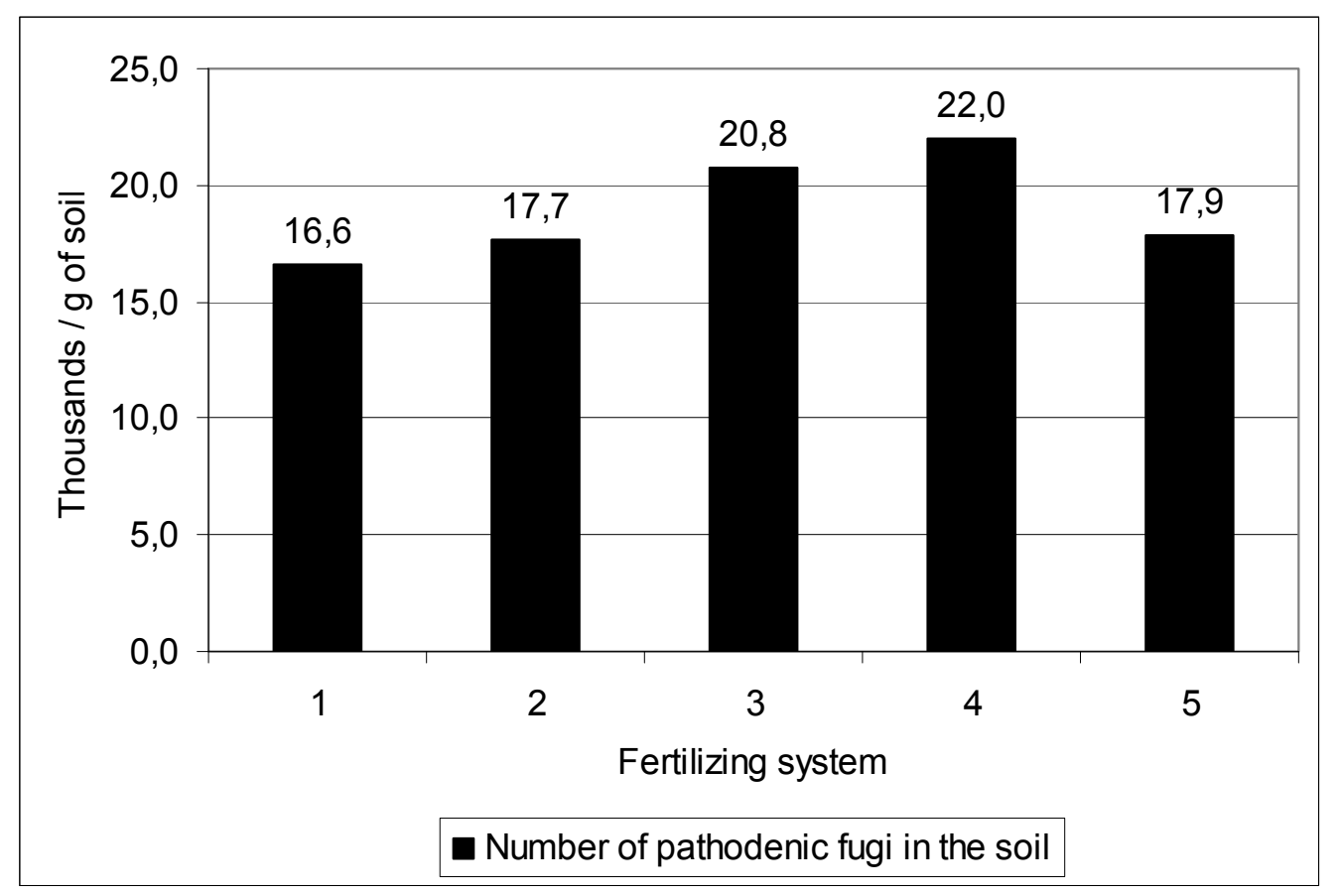

1-Without fertilizer; 2- $\mathrm{N}_{120} \mathrm{P}_{90} \mathrm{~K}_{90}+\mathrm{By}$-products predecessor.; 3- $\mathrm{N}_{135} \mathrm{P}_{135} \mathrm{~K}_{135}+\mathrm{By}$-products predecessor; 4By-products predecessor.; 5- $\mathrm{N}_{120} \mathrm{P}_{90} \mathrm{~K}_{90}$.

Fig. 3. The number of pathogenic fungi in the soil under winter wheat crops depending on fertilizing systems byby-products predecessor peas (Chabany, stationary experiment), 2004-2009.

The lowest number of pathogenic fungi noted in the variant without fertilization and plant residues peas (control) - 16.6 thousand. / G soil. Making fertilizer $\left(\mathrm{N}_{90} \mathrm{P}_{90} \mathrm{~K}_{90}\right)$ of plowing by-product predecessor peas boosted the number of pathogenic fungi to 17,7-17,9 thousand. / $G$ soil. The highest number of pathogenic fungi in soil was observed in the variant of plowing by-product precursor peas - 22.0 thousand. / $\mathrm{G}$ soil and by making $\mathrm{N}_{135} \mathrm{P}_{135} \mathrm{~K}_{135}$ against the background of plowing byproducts peas (20.8 thousand. / G soil).

\section{Conclusions}

1. The use of by-products peas, moderate doses of fertilizers, especially nitrogen - - kg. a.i. 60-120 / ha of nitrogen and potassium ratio of 1,33: 1 in winter wheat growing technologies provide favorable phytosanitarycondition of crops and restrict the use of fungicides and insecticides during the growing season crops.

2. Using of fertilizer doses $\mathrm{N}_{300} \mathrm{P}_{150} \mathrm{~K}_{150} ; \mathrm{N}_{120}, \mathrm{~N}_{240} \mathrm{P}_{80} \mathrm{~K}_{100} \mathrm{~N}_{180} \mathrm{P}_{135} \mathrm{~K}_{135}$ makes it possible to obtain high grain yield of winter wheat (7,0-9,0 t/ha and above), but there is increased infestation of plants with powdery mildew, Septoria leaf, root rot and colonization sucking pests, which requires intensive chemical plant protection from diseases and pests.

3. Increase in the number of pathogenic fungi in the soil contributed to increasing doses of fertilizer to $\mathrm{N}_{90} \mathrm{P}_{90} \mathrm{~K}_{90} \mathrm{~N}_{135} \mathrm{P}_{135} \mathrm{~K}_{135}$ and plowing by-products peas.

The article presents the results of years of research on the effects of different systems of fertilizers on the phytosanitary condition of winter wheat and the expediency of chemical crop protection during the growing season.

Established that the use of high doses of mineral fertilizers $\left(\mathrm{N}_{300} \mathrm{P}_{150} \mathrm{~K}_{150} ; \mathrm{N}_{120}, \mathrm{~N}_{240} \mathrm{P}_{80} \mathrm{~K}_{100}\right.$ and $\mathrm{N}_{180} \mathrm{P}_{135} \mathrm{~K}_{135}$ ) increases infestation of plants with powdery mildew, Septoria leaf, root rot, colonization sucking pests and contributes to the number of pathogenic fungi in the soil, which requires intensive chemical plant protection from disease and pests. 


\section{Bibliography}

1. Progressiruyushchiye bolezni ozimoy i yarovoy pshenitsy/L.N. Nazarova. A.A. Motovilin. L.G. Korneva. S.S. Sanin//Zashchita i karantin rasteniy. — 2006. - № 7. - S. 12-14.

2. Vinnichuk T.S. Urazhenist ozimoï pshenitsi khvorobami zalezhno vid sistem udobrennya za suchasnikh tekhnologiy viroshchuvannya/T.S. Vinnichuk. I.M. Svidinyuk//Zemlerobstvo. - 2005. - Vip. 77. - S. 60-65.

3. Vliyaniye mineralnykh udobreniy na porazhennost ozimoy pshenitsy kornevoy gnilyu $v$ umerennovlazhnoy zone Stavropolskogo kraya/E.A. Salenko. A.N. Esaulko. A.P. Shutko. A.I. Podkolzin//Sovremennyye problemy nauki i obrazovaniya. - 2014. — № 6. - S. 5-9.

4. Dovgan S.V. Ozima potrebu€ uvagi/S.V. Dovgan. O.M. Orlova. O.B. Syadrista//Karantin i zakhist. 2007. — № 10. - S. 19-20.

5. Characterisation of Colletotrichum sp. Isolates causing lupin antrachose/P. Talhinhas. J. NevesMartins. H. Oliveira. S. Sreenivasaprasad//Lupin - Ancient Crop for the New Millenium. 9 th. International Lupin Conference. 20-24 june 1999. Abstracts. - R. 325. Bibliografiya

6. Sanin S.S. Povysit uroven fitosanitarnoy bezopasnosti strany/S.S. Sanin//Zashchita i karantin rasteniy. -2000 . - № 12. - S. 3-7.

7. Glazunova N.N. Rol sistemy udobreniy v povyshenii pochvennogo plodorodiya/N.N. Glazunova. Yu.A. Bezgina. O.M. Khadzhiakhmetova//Sb. nauch. Trudov Sworld. - 2014. - T. 27. № 2. - S. 87-89.

8. Esaulko A.N. Effektivnost programmirovaniya urozhaynosti ozimoy pshenitsy na chernozeme vyshchelochennom Stavropolskoy vozvyshennosti/A.N. Esaulko. E.A. Ustimenko. A.Yu. Guruyeva//Sb. nauch. trudov Sworld po materialam mezhdunar. nauch.-prakt. konf. — 2012. — T. 46. № 4. — S. 95-98.

9. Nikitishen V.I. Ekologo-agrokhimicheskiye osnovy sbalansirovannogo primeneniya udobreniy $v$ adaptivnom zemledelii/V.I. Nikitishen. - M.: Nauka. 2003. - $183 \mathrm{~s}$.

10. Chulkina V.A. Integrirovannaya zashchita rasteniy: fitosanitarnyye sistemy i tekhnologii/ V.A. Chulkina. E.Yu. Toropova. G.Ya. Stetsov. - M.: Kolos. 2009. - 670 s. 